\title{
Front Matter: Volume 7867
}

, "Front Matter: Volume 7867," Proc. SPIE 7867, Image Quality and System Performance VIII, 786701 (24 January 2011); doi: 10.1117/12.888994

Event: IS\&T/SPIE Electronic Imaging, 2011, San Francisco Airport, California, SPIE. United States 
PROCEEDINGS

IS\&T / SPIE

Electronic

Imaging

SCIENCE AND TECHNOLOGY

\section{Image Quality and System Performance VIII}

Susan P. Farnand

Frans Gaykema

Editors

24-26 January 2011

San Francisco, California, United States

Sponsored and Published by

IS\&T-The Society for Imaging Science and Technology

SPIE 
The papers included in this volume were part of the technical conference cited on the cover and title page. Papers were selected and subject to review by the editors and conference program committee. Some conference presentations may not be available for publication. The papers published in these proceedings reflect the work and thoughts of the authors and are published herein as submitted. The publishers are not responsible for the validity of the information or for any outcomes resulting from reliance thereon.

Please use the following format to cite material from this book:

Author(s), "Title of Paper," in Image Quality and System Performance VIII, edited by Susan P. Farnand, Frans Gaykema, Proceedings of SPIE-IS\&T Electronic Imaging, SPIE Vol. 7867, Article CID Number (2011).

\title{
ISSN 0277-786X \\ ISBN 9780819484048
}

\author{
Copublished by \\ SPIE \\ P.O. Box 10, Bellingham, Washington 98227-0010 USA \\ Telephone +1 3606763290 (Pacific Time) · Fax +1 3606471445 \\ SPIE.org \\ and \\ IS\&T-The Society for Imaging Science and Technology \\ 7003 Kilworth Lane, Springfield, Virginia, 22151 USA \\ Telephone +1 7036429090 (Eastern Time) · Fax +1 7036429094 \\ imaging.org
}

Copyright (c) 2011, Society of Photo-Optical Instrumentation Engineers and The Society for Imaging Science and Technology.

Copying of material in this book for internal or personal use, or for the internal or personal use of specific clients, beyond the fair use provisions granted by the U.S. Copyright Law is authorized by the publishers subject to payment of copying fees. The Transactional Reporting Service base fee for this volume is $\$ 18.00$ per article (or portion thereof), which should be paid directly to the Copyright Clearance Center (CCC), 222 Rosewood Drive, Danvers, MA 01923. Payment may also be made electronically through CCC Online at copyright.com. Other copying for republication, resale, advertising or promotion, or any form of systematic or multiple reproduction of any material in this book is prohibited except with permission in writing from the publisher. The CCC fee code is $0277-786 \mathrm{X} / 11 / \$ 18.00$.

Printed in the United States of America.

Paper Numbering: Proceedings of SPIE follow an e-First publication model, with papers published first online and then in print and on CD-ROM. Papers are published as they are submitted and meet publication criteria. A unique, consistent, permanent citation identifier (CID) number is assigned to each article at the time of the first publication. Utilization of CIDs allows articles to be fully citable as soon they are published online, and connects the same identifier to all online, print, and electronic versions of the publication. SPIE uses a six-digit CID article numbering system in which:

- The first four digits correspond to the SPIE volume number.

- The last two digits indicate publication order within the volume using a Base 36 numbering system employing both numerals and letters. These two-number sets start with 00, 01, 02, 03, 04, 05, 06, 07, 08, 09, OA, OB ... 0Z, followed by 10-1Z, 20-2Z, etc.

The CID number appears on each page of the manuscript. The complete citation is used on the first page, and an abbreviated version on subsequent pages. Numbers in the index correspond to the last two digits of the six-digit CID number. 


\section{Contents}

ix Conference Committee

SESSION 1 IMAGE QUALITY IN PRINT

786702 Image quality metrics for the evaluation of print quality [7867-01]

M. Pedersen, Gjøvik Univ. College (Norway); N. Bonnier, Océ Print Logic Technologies S.A. (France); J. Y. Hardeberg, Gjøvik Univ. College (Norway); F. Albregtsen, Univ. of Oslo (Norway)

786703 Hyper error map based document stitching [7867-02]

C. Cui, Lexmark International, Inc. (United States)

786704 Quantification of perceived macro-uniformity [7867-03]

K.-Y. Lee, Y. Bang, H.-K. Choh, Samsung Electronics Co., Ltd. (Korea, Republic of)

786705 Comparing hardcopy and softcopy results in the study of the impact of workflow on perceived reproduction quality of fine art images [7867-04]

S. Farnand, J. Jiang, F. Frey, Rochester Institute of Technology (United States)

786706 Using metrics to assess the ICC perceptual rendering intent [7867-05]

K. Falkenstern, Océ Print Logic Technologies S.A. (France) and Institut TELECOM, TELECOM ParisTech, LTCl, CNRS (France); N. Bonnier, Océ Print Logic Technologies S.A. (France); M. Pedersen, Gjøvik Univ. College (Norway); H. Brettel, Institut TELECOM, TELECOM ParisTech, LTCl, CNRS (France); F. Viénot, Muséum National d'Histoire Naturelle (France) and Ctr. de Recherche sur la Conservation des Collections (France)

\section{SESSION 2 IMAGE QUALITY ATTRIBUTES CHARACTERIZATION AND MEASUREMENT I}

786707 Development of a perceptually calibrated objective metric of noise [7867-06]

B. W. Keelan, E. W. Jin, S. Prokushkin, Aptina Imaging Corp. (United States)

786708 Perceptually relevant evaluation of noise power spectra in adaptive pictorial systems [7867-07]

R. B. Jenkin, B. W. Keelan, Aptina Imaging Corp. (United States)

786709 A novel perceptual image quality measure for block based image compression [7867-08] T. Shoham, D. Gill, S. Carmel, ICVT Ltd. (Israel)

7867 OA Predicting preferred coring level to reduce toner scatter in electrophotographic printing [7867-09]

H. J. Park, Samsung Electronics Co., Ltd. (Korea, Republic of); J. P. Allebach, Purdue Univ. (United States) 
7867 OB A universal reference-free blurriness measure [7867-11]

C. Chen, W. Chen, J. A. Bloom, Dialogic Media Labs (United States)

7867 OC Issues in the design of a no-reference metric for perceived blur [7867-12]

H. Liu, Technische Univ. Delft (Netherlands); I. Heynderickx, Technische Univ. Delft

(Netherlands) and Philips Research Nederland B.V. (Netherlands)

7867 OD Evaluating super resolution algorithms [7867-13]

Y. J. Kim, J. H. Park, G. S. Shin, H.-S. Lee, D.-H. Kim, S. H. Park, J. Kim, Samsung Electronics Co., Ltd. (Korea, Republic of)

7867 OE Image quality assessment based on distortion identification [7867-14]

A. Chetouani, A. Beghdadi, L2TI, Institut Galilée, Univ. Paris 13 (France)

\section{SESSION 4 SYSTEM PERFORMANCE: CAPTURE}

7867 OF Image quality evaluation of light field photography [7867-15]

Q. Fu, Xi'an Institute of Optics and Precision Mechanics (China); Z. Zhou, Univ. Of Science and Technology of China (China); Y. Yuan, Beihang Univ. (China); B. Xiangli, The Academy of Opto-Electronics (China)

7867 OG Feature-based automatic color calibration for networked camera system [7867-16] S. Yamamoto, Tokyo Metropolitan College of Industrial Technology (Japan); K. Taki, N. Tsumura, T. Nakaguchi, Y. Miyake, Chiba Univ. (Japan)

$7867 \mathrm{OH} \quad$ Estimation error in image quality measurements [7867-17]

P. D. Burns, Carestream Health, Inc. (United States)

\section{SESSION 5 SYSTEM PERFORMANCE: VIDEO}

7867 OI LCD displays performance comparison by MTF measurement using the white noise stimulus method [7867-18]

C. Mitjà, J. Escofet, Univ. Politècnica de Catalunya (Spain)

7867 0J Improving the quality of H.264/AVC by using a new rate-quantization model [7867-19] M. Hrarti, XLIM-SIC Lab., Univ. of Poitiers (France) and GSCM-LRIT Lab., Univ. Mohamed V (Morocco); H. Saadane, XLIM-SIC Lab., Univ. of Poitiers (France) and Nantes Univ. (France); M. Larabi, XLIM-SIC Lab., Univ. of Poitiers (France); A. Tamtaoui, LTI Lab., National Institute of Post and Telecommunications (Morocco); D. Aboutajdine, GSCM-LRIT Lab., Univ. Mohamed $\checkmark($ Morocco)

7867 OK A noble method on no-reference video quality assessment using block modes and quantization parameters of H.264/AVC [7867-20]

I. Park, T. Na, M. Kim, KAIST (Korea, Republic of)

7867 OL Prioritization of application layer FEC information for IP television services QoS [7867-21]

E. Mammi, Univ. degli Studi di Roma Tre (Italy) and Fondazione Ugo Bordoni (Italy); G. Russo,

P. Talone, Fondazione Ugo Bordoni (Italy) 
7867 OM Reference image method for measuring quality of photographs produced by digital cameras [7867-22]

M. Nuutinen, Aalto Univ. School of Science and Technology (Finland); O. Orenius, T. Säämänen, Univ. of Helsinki (Finland); P. Oittinen, Aalto Univ. School of Science and Technology (Finland)

7867 ON RAW camera DPCM compression performance analysis [7867-23]

K. Bouman, V. Ramachandra, K. Atanassov, M. Aleksic, S. R. Goma, Qualcomm Inc. (United States)

SESSION 7 HIGH DYNAMIC RANGE IMAGING: JOINT SESSION WITH CONFERENCE 7876

786700 Brightness, lightness, and specifying color in high-dynamic-range scenes and images [7867-24]

M. D. Fairchild, P.-H. Chen, Rochester Institute of Technology (United States)

7867 OP Evaluating HDR photos using Web 2.0 technology [7867-25]

G. Qiu, Y. Mei, The Univ. of Nottingham (United Kingdom); J. Duan, Southwest Univ. of Finance and Economics (China)

\section{SESSION 8 PERCEPTUAL IMAGE QUALITY EXPERIMENTATION}

$78670 Q \quad J u s t$ noticeable difference vs. visual difference: hypotheses and how to verify their validity [7867-26]

S. Bezryadin, P. Burov, I. Tryndin, Unified Color Technologies LLC (United States)

7867 OR Device-dependent scene-dependent quality predictions using effective pictorial information capacity [7867-27]

K. H. Oh, S. Triantaphillidou, R. E. Jacobson, Univ. of Westminster (United Kingdom)

\section{SESSION 9 DISCUSSION ON WEB-BASED IQ TESTING}

7867 OS Social image quality [7867-28]

G. Qiu, A. Kheiri, The Univ. of Nottingham (United Kingdom)

\section{SESSION 10 SYSTEM PERFORMANCE: SECURITY}

7867 OT Utility studies for security encoded office documents: experimental design challenges [7867-29]

C. A. Deller, G. J. Woolfe, Canon Information Systems Research Australia Pty. Ltd. (Australia)

7867 OU Printed fingerprints: a framework and first results towards detection of artificially printed latent fingerprints for forensics [7867-30]

S. Kiltz, M. Hildebrandt, J. Dittmann, Otto-von-Guericke-Univ. Magdeburg (Germany);

C. Vielhaver, Fachhochschule Brandenburg (Germany); C. Kraetzer,

Otto-von-Guericke-Univ. Magdeburg (Germany) 
7867 OV Monitoring image quality for security applications [7867-31]

M.-C. Larabi, XLIM-SIC (France); D. Nicholson, Thales Communications S.A. (France)

7867 OW Video quality and interpretability study using SAMVIQ and Video-NIIRS [7867-32]

D. L. Young, Raytheon Intelligence and Information Systems (United States); J. Ruszczyk, General Dynamics Advanced Information Systems (United States); T. Bakir, Harris Corp. (United States)

SESSION 11 VISUAL ATTENTION, SALIENCY, AND QUALITY I: JOINT SESSION WITH CONFERENCE 7865

7867 OX Weighted-MSE based on saliency map for assessing video quality of H.264 video streams [7867-33]

H. Boujut, J. Benois-Pineau, LABRI, CNRS, Univ. Bordeaux 1 (France); O. Hadar, Ben-Gurion Univ. of the Negev (Israel); T. Ahmed, LABRI, CNRS, Univ. Bordeaux 1 (France); P. Bonnet, Audemat WorldCast Systems Group (France)

VISUAL ATTENTION, SALIENCY, AND QUALITY II: JOINT SESSION WITH CONFERENCE 7865

7867 OY Using performance efficiency for testing and optimization of visual attention models [7867-34]

B. J. Stankiewicz, N. J. Anderson, R. J. Moore, 3M Company (United States)

$78670 Z$ Naturalness and interestingness of test images for visual quality evaluation [7867-35]

R. Halonen, S. Westman, P. Oittinen, Aalto Univ. School of Science and Technology (Finland)

INTERACTIVE PAPER SESSION

786710 Potential of face area data for predicting sharpness of natural images [7867-36] M. Nuutinen, Aalto Univ. School of Science and Technology (Finland); O. Orenius, T. Säämänen, Univ. of Helsinki (Finland); P. Oittinen, Aalto Univ. School of Science and Technology (Finland)

786711 A video quality assessment model based on the MPEG-7 descriptor [7867-37] M. Sato, Y. Horita, Univ. of Toyama (Japan)

786712 Image quality: a tool for no-reference assessment methods [7867-38]

S. Corchs, F. Gasparini, F. Marini, R. Schettini, Univ. degli Studi di Milano-Bicocca (Italy)

786713 Extending video quality metrics to the temporal dimension with 2D-PCR [7867-39]

C. Keimel, M. Rothbucher, K. Diepold, Technische Univ. München (Germany)

786714 ImQual: a web-service dedicated to image quality evaluation and metrics benchmark [7867-41]

M. Nauge, M.-C. Larabi, C. Fernandez-Maloigne, XLIM-SIC Lab., Univ. of Poitiers (France)

786715 Optimal front light design for reflective displays under different ambient illumination [7867-42]

S.-P. Wang, T.-T. Chang, C.-J. Li, Y.-H. Bai, K.-J. Hu, Industrial Technology Research Institute (Taiwan) 
786716 Comparison of HDTV formats in a consumer environment [7867-43]

C. Keimel, A. Redl, K. Diepold, Technische Univ. München (Germany)

Author Index 
Downloaded From: https://www.spiedigitallibrary.org/conference-proceedings-of-spie on 26 Apr 2023

Terms of Use: https://www.spiedigitallibrary.org/terms-of-use 


\title{
Conference Committee
}

\author{
Symposium Chair
}

Sabine E. Süsstrunk, École Polyłechnique Fédérale de Lausanne

(Switzerland)

Symposium Cochair

Majid Rabbani, Eastman Kodak Company (United States)

Conference Chairs

Susan P. Farnand, Rochester Institute of Technology (United States)

Frans Gaykema, Océ Technologies B.V. (Netherlands)

Program Committee

Peter D. Burns, Carestream Health, Inc. (United States)

Majed Chambah, Université de Reims Champagne-Ardenne (France)

Luke C. Cui, Lexmark International, Inc. (United States)

Mark D. Fairchild, Rochester Institute of Technology (United States)

Dirk W. Hertel, Sensata Technologies, Inc. (United States)

Robin B. Jenkin, Aptina Imaging Corporation (United States)

Sang Ho Kim, Samsung Electronics Company, Ltd. (Korea, Republic of)

Mohamed-Chaker Larabi, Université de Poitiers (France)

Lindsay W. MacDonald, London College of Communication (United Kingdom)

Yoichi Miyake, Chiba University (Japan)

Göte S. Nyman, University of Helsinki (Finland)

Sophie Triantaphillidou, University of Westminster (United Kingdom)

Eric K. Zeise, Kodak's Graphic Communications Group (United States)

Hongqin Zhang, Apple Inc. (United States)

D. René Rasmussen, Qi Analytics LLC (United States)

Session Chairs

Image Quality in Print

Frans Gaykema, Océ Technologies B.V. (Netherlands)

Image Quality Attributes Characterization and Measurement I

Sophie Triantaphillidou, University of Westminster (United Kingdom)

Image Quality Attributes Characterization and Measurement II

Luke C. Cui, Lexmark International, Inc. (United States) 
System Performance: Capture

Göte S. Nyman, University of Helsinki (Finland)

System Performance: Video

Mohamed-Chaker Larabi, Université de Poitiers (France)

Image Quality Issues in Digital Photography: Joint Session with

Conference 7876

Peter D. Burns, Carestream Health, Inc. (United States)

Jon S. McElvain, Digital Imaging Systems (United States)

High Dynamic Range Imaging: Joint Session with Conference 7876

Susan P. Farnand, Rochester Institute of Technology (United States)

Ricardo J. Motta, Attom Research (United States)

Perceptual Image Quality Experimentation

Mark D. Fairchild, Rochester Institute of Technology (United States)

System Performance: Security

Robin B. Jenkin, Aptina Imaging Corporation (United States)

Visual Attention, Saliency, and Quality I: Joint Session with Conference 7865

Susan P. Farnand, Rochester Institute of Technology (United States) Bernice E. Rogowitz, Visual Perspectives Consulting (United States) Thrasyvoulos N. Pappas, Northwestern University (United States)

Visual Attention, Saliency, and Quality II: Joint Session with Conference 7865

Susan P. Farnand, Rochester Institute of Technology (United States)

Bernice E. Rogowitz, Visual Perspectives Consulting (United States)

Thrasyvoulos N. Pappas, Northwestern University (United States) 